\title{
Exploration of Trichoderma spp. as an Effective Bio Control Agents against the Sclerotial wilt Caused by Sclerotium rolfsii Sacc.
}

\author{
M. Priyadharcini ${ }^{1}$, R. Akila ${ }^{1 *}$, M.L. Mini ${ }^{2}$, N. Rajinimala ${ }^{1}$ and R. Kannan ${ }^{1}$ \\ ${ }^{1}$ Department of Plant Pathology, ${ }^{2}$ Department Biochemistry, Soil Science and Agricultural \\ Chemistry, Tamil Nadu Agricultural University, AC\&RI, Killikulam, Vallanad-628 252, \\ Tuticorin District, Tamil Nadu, India \\ *Corresponding author
}

\section{A B S T R A C T}

\begin{tabular}{|l|}
\hline K e y w o r d s \\
$\begin{array}{l}\text { Sclerotium rolfsii, } \\
\text { Jasmine, ITS region, } \\
\text { Oxalic acid, Volatile } \\
\text { metabolites, Trichoderma } \\
\text { harzianum }\end{array}$ \\
\hline Article Info \\
\hline $\begin{array}{l}\text { Accepted: } \\
\text { 10 July } 2018 \\
\text { Available Online: } \\
\text { 10 August } 2018\end{array}$ \\
\hline
\end{tabular}

\section{Introduction}

India is having favourable agroclimatic conditions for the production of flower crops. Floriculture is a fast emerging and highly competitive industry in our country. Jasmine is one of the ancient flowers grown in India. It comes under the family Oleaceae, order Oleales and genus Jasminum. Jasmine is a queen of flowers and is called the "Queen of fragrance" or "Queen of the Night". The word jasmine is derived from an Arabic word "Jessamine" called as "Yasmin" or yasmyn" which means fragrance. Scented oil is mainly
Jasmine is the most attractive flower crop being cultivated throughout the tropical and subtropical countries. In Tamil Nadu jasmine cultivation is highly interrupted by the soil borne wilt pathogen Sclerotium rolfsii Sacc. In the current scenario of disease management of soil borne pathogens Trichoderma spp can be effectively exploited for the effective containment of the disease. The isolate SR1 was found to be the most virulent during the surveillance programme and it produced the maximum amount of host non-specific toxin oxalic acid. The Trichoderma species such as $T$. harzianum (TspT), Trichoderma sp. (TspK) and $T$. viride 1 performed well and inhibited the mycelial growth effectively. The isolate TspT excelled in toxin degradation. The ITS region of TspT was amplified with $T$. harzianum in the NCBI-Blast search. 
Sclerotium wilt and blight (Tang et al., 2015). This pathogen is having a wide host range which include alfalfa, banana, bean, beet, brussels sprouts, cabbage, carrot, cauliflower, celery, chrysanthemum, coffee, cotton, cucumber, garlic, ginger, gourd, lettuce, mango, muskmelon, mustard, onion, southern pea, peanuts, pineapple, potato, pumpkin, radish, soybean, squash, tobacco, tulip, turf, turnip, and yam (Aycock, 1966).

The annual loss to world crops has been estimated as about 30,000 million dollars due to this fungal pathogen $S$. rolfsii (Chaurasia et al., 2014). Rolfs (1893) first noticed the unnamed fungus as tomato blight in Florida. Saccardo (1911) named the fungus as Sclerotium rolfsii which was sterile consisting of hyphae and sclerotia. It is a well-known polyphagous and most destructive soil borne fungus.S. rolfsii forms brownish sclerotia that can survive in soil for long period tolerating biological and chemical degradation due to the presence of melanin in the outer membrane (Chet, 1975) (Fig. 1a, b and c).

S. rolfsii secrete non-host specific phytotoxin, oxalic acid and tissue degrading enzyme cellulase during infection process and it is corrosive to plant tissues. Oxalic acid combine with calcium in plant tissues, removing it from association with the pectic compounds in plant cell walls, lowering cell wall $\mathrm{pH}$, and thereby favouring the activity of the cell walldegrading enzymes polygalacturonase and cellulase. Oxalic acid and tissue degrading enzymes work together to break down the cell walls and resulting in tissue maceration. The pathogens then absorb nutrients from the macerated tissue. Maceration interrupts transport of water and nutrients in plant tissues, thereby causing wilting, yellowing and necrosis (Billah, 2017).

Usage of bio control agents and their antibiotics, is an alternative method for chemical control. It is a safe, effective and ecofriendly approach in plant disease management(Wang et al., 1999).The biocontrol mechanism involved in Trichoderma spp. were competition for nutrients and space, mycoparasitism, antibiosis, production of volatile metabolites and hydrolytic enzymes such as $\beta-13$ glucanase and chitinase which partially degrades the cell wall of the pathogen and leads to parasitization (Kubicek et al., 2001). Trichoderma spp. came into contact with the pathogenic fungi, they attached and coiled around the pathogens and formed appressoria for infection. Holes are produced at the site of appressorial contact and Trichoderma entered into the lumen of the target fungi and killed the target fungi (Harman et al., 2004).

\section{Materials and Methods}

\section{Source of the pathogen}

A survey was conducted in jasmine growing areas of southern districts of Tamil Nadu and it was noticed that highest disease incidence (70.00 per cent) was recorded at Kalvai, Srivaikundam, Thoothukudi district (SR1). The pathogen was isolated and named as SR1. The pathogenicity experiment was conducted to test the virulence of the isolates and prove the Koch's postulates. In this test the isolate SR1was found highly virulent by recording the highest per cent disease incidence $(93.50 \%)$ as compared with other isolates and was forwarded for doing other experiments. This isolate produced the typical wilt symptoms on the artificially inoculated jasmine plants in pot culture.

\section{Isolation of bacterial and fungal antagonists from the rhizosphere region of Jasmine plants}

Ten gram of rhizosphere soil was transferred to $250 \mathrm{ml}$ Erlenmeyer flask containing $100 \mathrm{ml}$ 
of sterile distilled water. The antagonist in the suspension was isolated by serial dilution plate method after thorough shaking (Pramer and Schmidt, 1956). From the final dilutions of $10^{-}$ $3,10^{-5}$ and $10^{-6}$ one $\mathrm{ml}$ of each aliquot was pipetted out, poured in sterilized Petri plate containing Trichoderma selective medium (TSM), King's B medium and Nutrient agar medium separately and they were gently rotated clockwise and anti-clockwise for uniform distribution and incubated at room temperature $\left(28 \pm 2^{\circ} \mathrm{C}\right)$ for 24 hours in case of bacteria and seven days in case of fungi. The colonies were viewed under UV light. Colonies with characteristics of Bacillus spp. and Pseudomonas spp. were isolated individually and purified by "streak plate method" (Ranaswami, 1993) on Nutrient agar medium and King's B medium respectively. Trichoderma sp. isolated from TSM was purified and maintained on PDA medium. The pure cultures were maintained on respective agar slants at $4^{\circ} \mathrm{C}$. Trichoderma spp. isolated from Thovalai, Kanyakumari Dt. and Kalvai, Srivaikundam, Thoothukudi Dt. were named shortly as $\mathrm{Tsp}_{\mathrm{T}}(\mathrm{TOV})$ and $\mathrm{Tsp}_{\mathrm{K}}$. (KAL). Like this Pseudomonas spp. as $\mathrm{Psp}_{\mathrm{T}}(\mathrm{TOV}), \mathrm{Psp}_{\mathrm{K}}$ (KAL) and Bacillus spp. as $\mathrm{Bsp}_{\mathrm{T}}(\mathrm{TOV})$ and $\mathrm{Bsp}_{\mathrm{K}}(\mathrm{KAL})$. In addition to this the standard bio control agents being maintained in the department of Plant Pathology, AC and RI Killikulam such as Trichoderma viride (Tv1), Pseudomonas fluorescens (Pf1) and Bacillus amyloliquefaciens were used against $S$. rolfsii.

\section{Efficacy of fungal and bacterial bio control agents against the growth of $S$. rolfsii in vitro Dual culture technique}

The antagonistic effect of three isolates of Trichoderma sp. $\left(\mathrm{Tsp}_{\mathrm{K}}, \mathrm{Tsp}_{\mathrm{T}}, \mathrm{Tv}_{1}\right)$, Bacillus spp. (Bsp $\mathrm{B}_{\mathrm{K}}, \mathrm{Bsp}_{\mathrm{T}}$, B. amyloliquefaciens) and Pseudomonas spp. $\left(\mathrm{Psp}_{\mathrm{K}}, \mathrm{Psp}_{\mathrm{T}}, \mathrm{Pf} 1\right)$ were tested against the pathogen by dual culture method(Dennis and Webster, 1971). As the pathogen is a fast growing it was inoculated against the pathogen simultaneously. The Petri plates containing medium inoculated with the pathogen alone were served as control. The radial growth of the pathogen was measured in all the treatments when full growth of the fungus was seen in the control plate. The results were expressed as per cent inhibition over control by using the formula described by Pandey and Upadhyay (2000).

\section{Molecular characterization of Trichoderma sp. $\left(\operatorname{Tsp}_{\mathrm{T}}\right)$}

Genomic DNA extraction from Trichoderma sp.

Isolation of fungal genomic DNA was done by the method described by Chakraborty et al., (2010). To verify the quality of isolated DNA, $2.5 \mu 1$ of total DNA solution was resolved in the $1 \%$ agarose gel electrophoresis.

\section{Agarose gel electrophoresis}

One gram of agarose was added to the $100 \mathrm{ml}$ of $1 \mathrm{X}$ TAE buffer in a $250 \mathrm{ml}$ conical flask and melted until it turned to a clear, transparent solution in microwave oven. When the molten agarose gel was cooled to $55^{\circ} \mathrm{C}$, ethidium bromide was added to a final concentration of $0.5 \mu \mathrm{g} / \mathrm{ml}(5 \mu \mathrm{l}$ of $10 \mathrm{mg} / \mathrm{ml}$ ethidium bromide stock is added to $100 \mathrm{ml}$ solution) and the solution was mixed by gentle swirling. Warm agarose solution was poured into gel casting tray to a thickness of 5-10 mm and the comb was placed to make wells to load the DNA samples in the gel. The gel was kept at room temperature for 30-45 minutes to set completely. Gel along with the casting tray was placed into electrophoresis tank filled with $1 \mathrm{X}$ TAE buffer. The comb was carefully removed from the gel. The samples were mixed with 6X loading dye. Slowly the samples were loaded into the wells of the submerged gel using a micropipette. DNA ladder was added to the left or right side of the 
gel as a marker. The lid of the gel tank was closed and electrical leads were attached to the tank. A voltage of 5-8 V/cm was applied. The gel electrophoresis was run until the bromophenol blue and xylene cyanol FF have migrated to $3 / 4^{\text {th }}$ distance from the top of the gel. The gel was examined under a UV light and the image was documented using Gel Doc apparatus.

\section{ITS Sequencing of Trichoderma}

A PCR was performed in a total volume of 50 $\mu l$ using Emerald Amp ${ }^{\circledR}$ GT PCR master mix using genomic DNA of Trichoderma as a template. The intermediate $5.8 \mathrm{~S}$ ribosomal gene along with ITS1 and ITS2 region were amplified using the primers ITS1 and ITS4 with the PCR conditions initial denaturing at $94^{\circ} \mathrm{C}$ for $5 \mathrm{~min}$. followed by 30 cycles of denaturation at $94{ }^{\circ} \mathrm{C}$ for $30 \mathrm{sec}$, annealing at $59{ }^{\circ} \mathrm{C}$ for $30 \mathrm{sec}$ and extension at $70{ }^{\circ} \mathrm{C}$ for 2 min and the final extension at $72{ }^{\circ} \mathrm{C}$ for $7 \mathrm{~min}$. The reaction was carried out in a Eppendorf master cycler gradient PCR machine. The PCR products were resolved by electrophoresis in 1\% agarose gel. The PCR products were purified using Favor Prep GEL/ PCR purification kit and sequenced at Eurofins genomics India Pvt. Ltd. Bangalore.

The Primers used for amplification of ITS region were

ITS1 - 5' TCCGTAGGTGAACCTGCGG 3' (forward primer)

ITS4 - 5' TCCTCCGCTTATTGATATGC3' (reverse primer)

Sequencing of ITS and identification of Trichoderma sp. by bioinformatics analysis

The obtained DNA sequences were trimmed at 5'and 3' region where the sequencing chromatogram were not clear. Then DNA sequence, in which clear chromatogram obtained, was made in Fasta format. This was used as input sequence (Query sequence) in nucleotide blast analysis program at NCBI database. The output data retrieved from the bioinformatics were analysed and, the organism showing major score was considered as the closely related species to the test fungus used in the study.

\section{Efficacy of volatile metabolites produced by the bio control against $S$. rolfsii in vitro}

PDA culture discs of $9 \mathrm{~mm}$, diameter of the fungal antagonists were kept at the centre of the Petri plates containing sterilized PDA medium. In case of bacterial antagonists 48 hour old culture of Pseudomonas spp. and Bacillus spp. were streaked at the centre of the Petri plates containing King's B and Nutrient agar medium respectively. The plates were incubated at room temperature. After incubation period, the lid of each Petri plates was replaced by another bottom plate containing PDA medium inoculated with $9 \mathrm{~mm}$ actively growing $S$. rolfsii. The two plates were sealed together and in case of control only the pathogen had been maintained in the upper lid along with the absence of antagonist. Five replications were maintained for each treatment. The colony diameter of the pathogen was measured on third day after inoculation. Data were expressed in per cent reduction over control.

\section{Degradation of oxalic acid production by bio control agents}

Czapek-Dox broth was prepared and $100 \mathrm{ml}$ was poured into $250 \mathrm{ml}$ conical flask and autoclaved at $121^{\circ} \mathrm{C}$ for $15 \mathrm{~min}$. For evaluating the effect of antagonists against oxalic acid production by $S$. rolfsii, the flasks were inoculated with $S$. rolfsii culture disc in one side and on other side the flasks were inoculated with the culture discs of fungal 
antagonist. For bacterial antagonists, cell suspension was prepared and inoculated with a loopful of culture. Czapek-Dox broth inoculated with $S$. rolfsii alone served as a control. The mycelial mat were removed by filtering the broth through Whatman No. 1 filter paper and the aliquots were centrifuged at $5000 \mathrm{rpm}$ for $10 \mathrm{~min}$ to remove the mycelial fragments. $8 \mathrm{ml}$ of calcium chloride-acetate buffer ( $\mathrm{pH} 4.5$ ) was added to $10 \mathrm{ml}$ of culture filtrate and mixed thoroughly.

Allowed the mixture to stand overnight and centrifuged at $5000 \mathrm{rpm}$ for $10 \mathrm{~min}$, supernatant was discarded and the residue was washed with $10 \mathrm{ml}$ of $\mathrm{H}_{2} \mathrm{SO}_{4}$. The solution was transferred to $100 \mathrm{ml}$ conical flask and heated at $80^{\circ} \mathrm{C}$ on water bath. While hot it was then titrated with $0.02 \mathrm{~N}$ potassium permanganate until faint pink colour persisted. $1 \mathrm{ml}$ of 0.02 $\mathrm{N}$ potassium permanganate reacted with $1.2653 \mathrm{mg}$ of oxalic acid. The oxalic acid present in the culture filtrate was calculated and expressed as $\mathrm{mg} / \mathrm{ml}$ (Mahadevan and Sridar, 1986).

\section{Results and Discussion}

\section{Dual culture technique}

Among these biocontrol agents, Trichoderma $\mathrm{sp} . \mathrm{Tsp}_{\mathrm{T}}(\mathrm{TOV})$ performed better and resulted maximum mycelial growth reduction of $S$. rolfsii (81.27 per cent) over control followed by $\mathrm{Tsp}_{\mathrm{K}}(\mathrm{KAL})$ (71.91 per cent reduction) and Tv1(66.29 per cent reduction). The isolate $\mathrm{Tsp}_{\mathrm{T}}$ grows over the pathogen and completely inhibit the sclerotial production. Trichoderma sp. attacked the $S$. rolfsii by adopting various mechanisms like coiling of hyphae, formation of holes and appressoria on the pathogenic cell wall. Due to the production of $\beta-1,3$ glucanase and chitinase enzymes it produces holes on the cell wall of the pathogen. All the above said mechanism have been observed in the dual culture technique (Elad et al., 1983). In the present investigation our best antagonist $T$. harzianum $\left(\mathrm{Tsp}_{\mathrm{T}}\right)$ grew faster than the $S$. rolfsii in dual plate method. This is highly advantage of the antagonist and effectively utilize the space and nutrients more than the pathogen (Table 1; Fig. 2).

Efficacy of volatile metabolites produced by the biocontrol agents against the pathogen in vitro

The bacterial and fungal bio control agents were tested for the production of volatile compounds using inverted plate technique. Among the tested isolates, T. viride (Tv1) and $\mathrm{Tsp}_{\mathrm{K}}$ were on par with each other and reduced the mycelial growth to 1.23 and $1.33 \mathrm{~cm}$ against the control $(9.00 \mathrm{~cm})$. The second best isolate is Trichoderma sp. $\left(\operatorname{Tsp}_{\mathrm{T}}\right.$ ) (Table 2; Fig. 3). Besides mycoparasitism, Trichoderma spp. produces diffusable metabolites which are volatie in nature. Humpty number of volatile secondary metabolites produced by Trichoderma sp. such as ethylene, hydrogen cyanide, aldehydes and ketones which play an important role in controlling the plant pathogen (Bhagat et al., 2014).

\section{Identification and confirmation of Trichoderma sp. by molecular technique}

The ITS region of Trichoderma $\mathrm{sp}$. $\left(\mathrm{Tsp}_{\mathrm{T}}\right)$ isolatewas amplified with primers ITS 1 and ITS 4 using a thermocycler and the products produced were visualised as a single band in agarose gel stained with Ethidium bromide. The size of the PCR fragment was approximately $650 \mathrm{bp}$ length. When the ITS sequence of the Trichoderma sp. $\left(\mathrm{Tsp}_{\mathrm{T}}\right)$ was BLAST searched in the NCBI data base, the output data showed matching sequences of Trichoderma harzianum. So the Trichoderma sp. $\left(\mathrm{Tsp}_{\mathrm{T}}\right)$ isolate used in the present study was confirmed as Trichoderma harzianum (Fig. 4). This is agreement with findings of Chakraborty et al., (2010). 
Plate.1Field view of jasmine affected by Sclerotium rolfsii
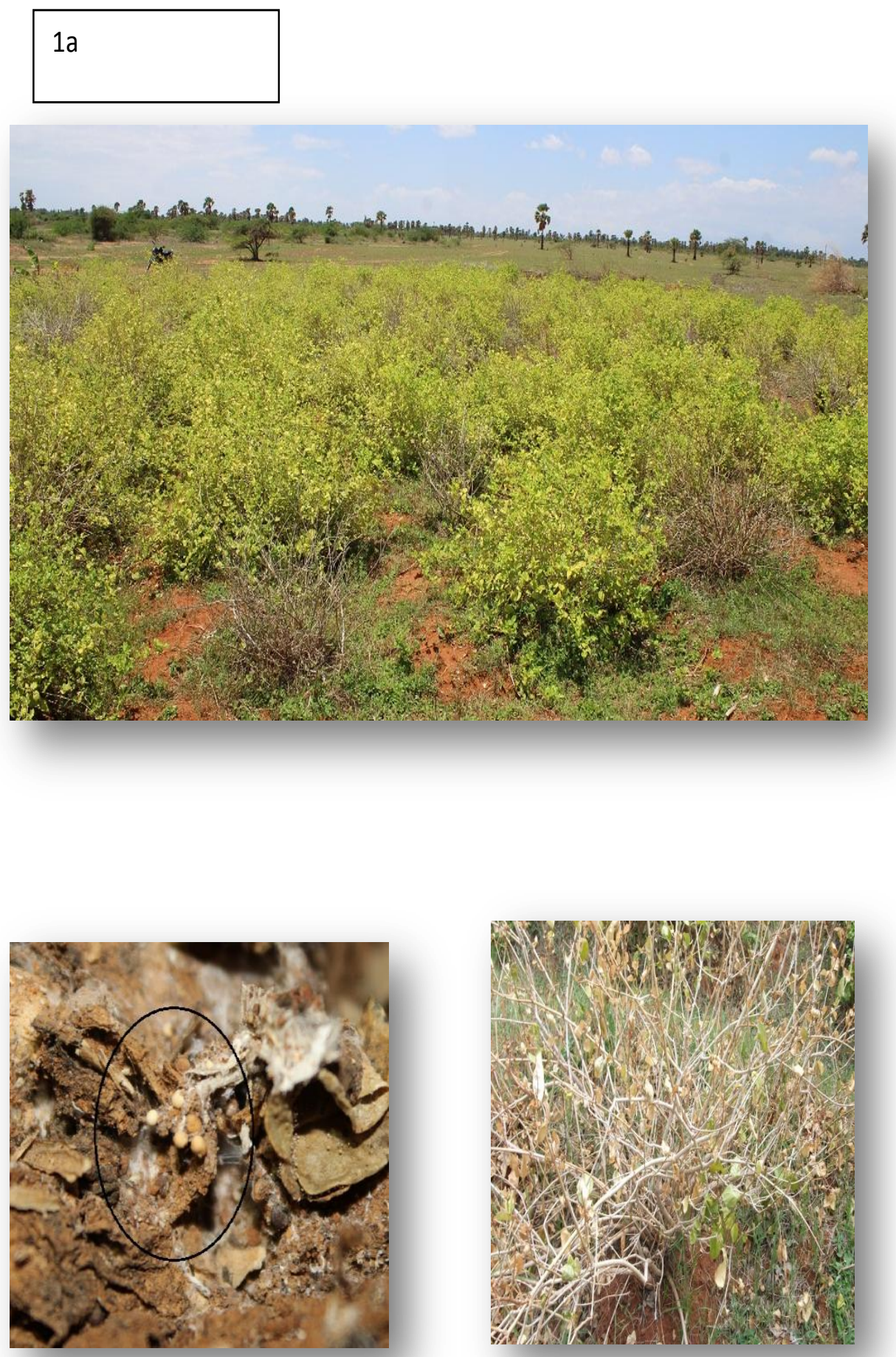

1b. Sclerotia and fluffy mycelium on plant debris

1c. Wilted plant 
Fig.2 Effect of bio control agents on the mycelia growth of S.rolfsii (Dual plate method)

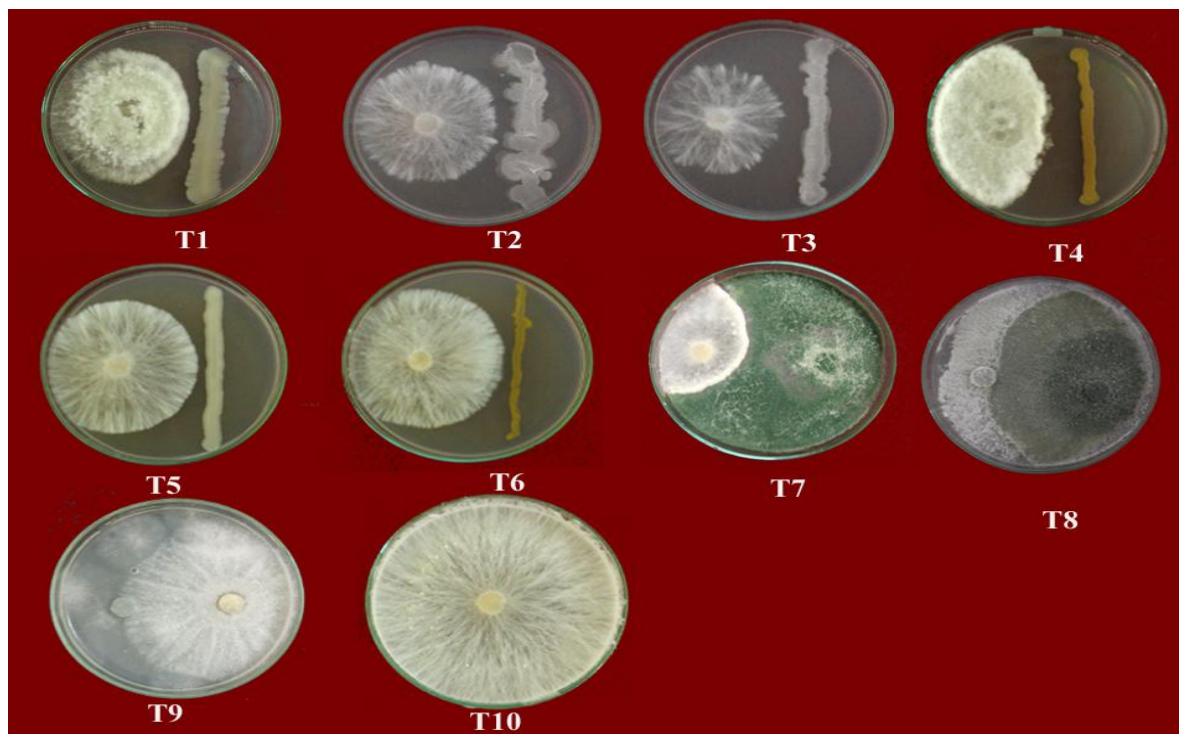

T1 -B. amyloliquefaciens

T2 -Bsp

T3 -Bsp

T4 - P. fluorescens (Pf1) T5 -Psp
T6 - Psp $_{\mathrm{K}}$

T7 - T. viride(Tv1)

T8 - Tsp $_{\mathrm{K}}$

T9 - Tsp $_{\mathrm{T}}$

T10 - Control

Fig.3 Effect of volatile metabolites produced by the bio control agents against the mycelial growth of $S$. rolfsii

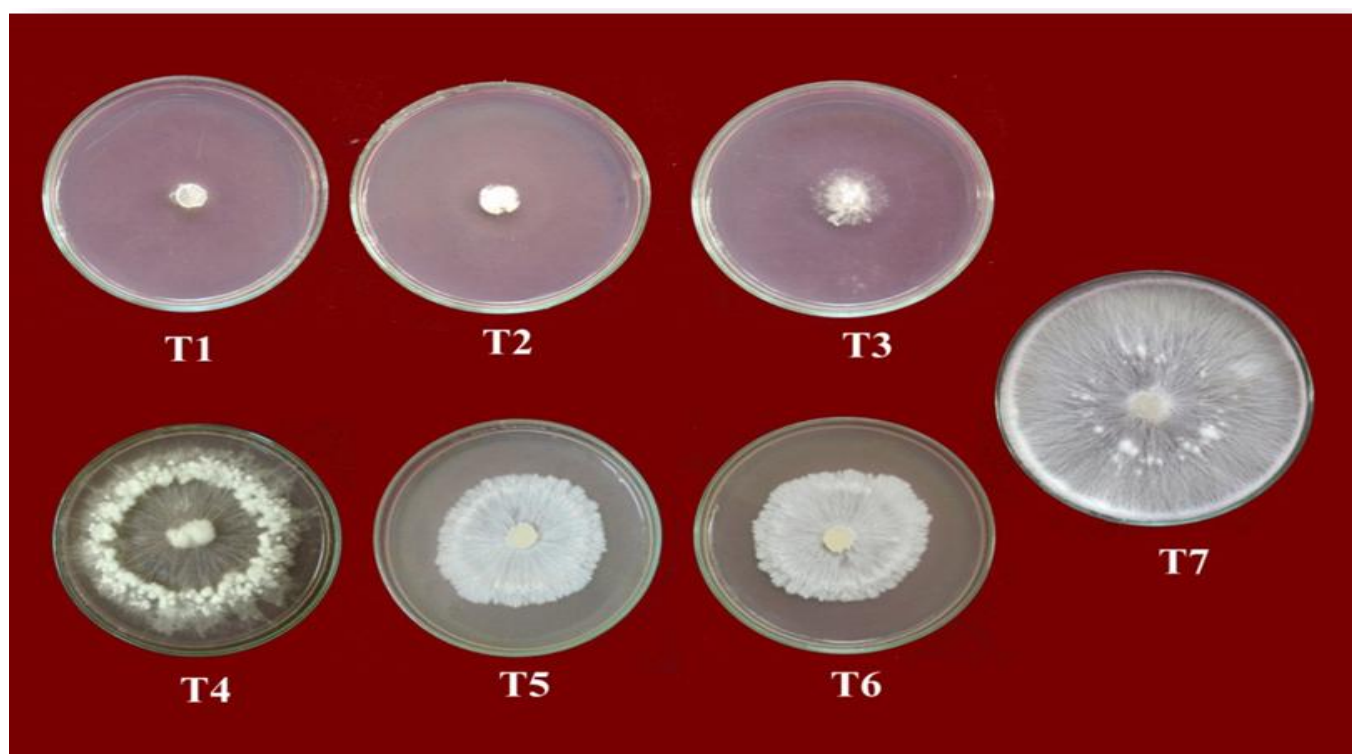

T1. T. viride (Tv1)

T2. $\quad \operatorname{Tsp}_{\mathrm{K}}$

T3. $\quad$ Tsp $_{\mathrm{T}}$

T4. P. fluorescens (Pf1)
T5. B. amyloliquefaciens

T6. $\quad$ Bsp $_{\mathrm{K}}$

T7. Control 


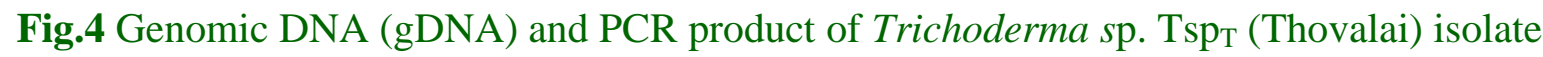

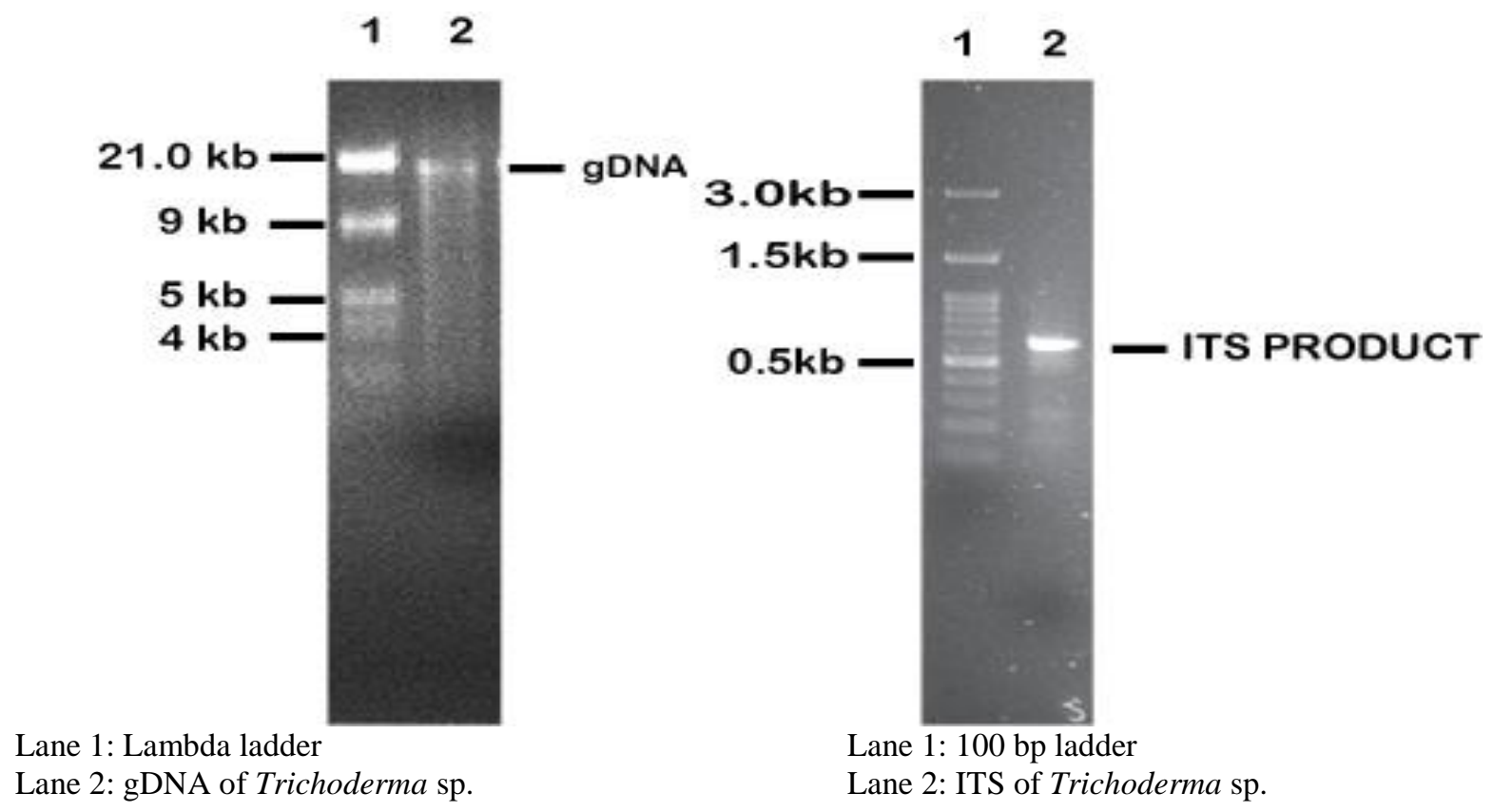

Table.1 Effect of bio control agents against the mycelial growth of S. rolfsii (Dual culture technique)

\begin{tabular}{|c|c|c|c|}
\hline Treatment & Bio control agents & $\begin{array}{l}\text { *Mycelial growth of the } \\
\text { pathogen }(\mathrm{cm})\end{array}$ & $\begin{array}{c}\text { Per cent inhibition over } \\
\text { control* }\end{array}$ \\
\hline$T_{1}$ & Bacillus amyloliquefaciens & 5.00 & $\begin{array}{c}43.82 \\
(41.45)^{\mathrm{d}}\end{array}$ \\
\hline$\overline{T_{2}}$ & $\mathrm{Bsp}_{\mathrm{T}}(\mathrm{TOV})$ & 5.24 & $\begin{array}{c}41.09 \\
(39.86)^{d}\end{array}$ \\
\hline $\mathbf{T}_{3}$ & $\mathrm{Bsp}_{\mathrm{K}}(\mathrm{KAL})$ & 5.10 & $\begin{array}{c}42.70 \\
(40.80)^{d}\end{array}$ \\
\hline $\mathbf{T}_{4}$ & Pseudomonas fluorescens(Pf1) & 5.05 & $\begin{array}{c}43.22 \\
(41.10)^{d}\end{array}$ \\
\hline $\mathbf{T}_{5}$ & $\mathrm{Psp}_{\mathrm{T}}(\mathrm{TOV})$ & 6.33 & $\begin{array}{c}28.84 \\
(32.46)^{\mathrm{e}}\end{array}$ \\
\hline $\mathrm{T}_{6}$ & $\operatorname{Psp}_{K}(\mathrm{KAL})$ & 7.27 & $\begin{array}{c}18.35 \\
(25.32)^{\mathrm{f}}\end{array}$ \\
\hline$\overline{T_{7}}$ & Trichodermaviride (Tv1) & 3.00 & $\begin{array}{c}66.29 \\
(54.51)^{\mathrm{c}}\end{array}$ \\
\hline$T_{8}$ & $\mathrm{Tsp}_{\mathrm{K}}(\mathrm{KAL})$ & 2.50 & $\begin{array}{c}71.91 \\
(58.07)^{\mathrm{b}}\end{array}$ \\
\hline$\overline{T_{9}}$ & $\operatorname{Tsp}_{\mathrm{T}}(\mathrm{TOV})$ & 1.67 & $\begin{array}{c}81.27 \\
(64.41)^{\mathrm{a}}\end{array}$ \\
\hline$\overline{T_{10}}$ & Control & 8.90 & 0.00 \\
\hline \multicolumn{3}{|c|}{$\mathrm{CD}(\mathrm{p}=0.05)$} & 2.56 \\
\hline
\end{tabular}

*Mean of five observations

The treatment means are compared using Duncan multiple range test (DMRT)

Values in parentheses are arcsine transformed

In a column, mean followed by a common letter ( $\mathrm{s}$ ) are not significantly different $(\mathrm{p}=0.05)$. 
Table. 2 Effect of volatile metabolites produced by bio control agents against the mycelial growth of $S$. rolfsii in vitro

\begin{tabular}{|c|c|c|c|}
\hline Treatment & Bio control agents & $\begin{array}{l}\text { *Mycelial growth } \\
\text { of the pathogen } \\
(\mathrm{cm})\end{array}$ & $\begin{array}{l}\text { Per cent inhibition } \\
\text { over control* }\end{array}$ \\
\hline $\mathbf{T}_{1}$ & Trichodermaviride (Tv1) & 1.23 & $\begin{array}{c}86.30 \\
(68.28)^{\mathrm{a}}\end{array}$ \\
\hline$\overline{T_{2}}$ & $\mathrm{Tsp}_{\mathrm{T}}(\mathrm{TOV})$ & 2.23 & $\begin{array}{c}75.19 \\
(60.30)^{b}\end{array}$ \\
\hline$\overline{T_{3}}$ & $\operatorname{Tsp}_{K}(\mathrm{KAL})$ & 1.33 & $\begin{array}{c}85.19 \\
(67.38)^{\mathrm{a}}\end{array}$ \\
\hline$\overline{\mathbf{T}_{4}}$ & Pseudomonas fluorescens(Pf1) & 6.60 & $\begin{array}{c}26.67 \\
(30.86)^{d}\end{array}$ \\
\hline$\overline{T_{5}}$ & Bacillus amyloliquefaciens & 4.50 & $\begin{array}{c}50.00 \\
(45.00)^{\mathrm{c}}\end{array}$ \\
\hline$\overline{T_{6}}$ & $\mathrm{Bsp}_{\mathrm{K}}(\mathrm{KAL})$ & 7.07 & $\begin{array}{c}21.48 \\
(27.61)^{d}\end{array}$ \\
\hline$\overline{T_{7}}$ & Control & 9.00 & 0.00 \\
\hline \multicolumn{3}{|c|}{$\mathrm{CD}(\mathrm{p}=0.05)$} & 1.79 \\
\hline
\end{tabular}

*Mean of five observations

The treatment means are compared using Duncan multiple range test (DMRT)

Values in parentheses are arcsine transformed

In a column, mean followed by a common letter ( $\mathrm{s})$ are not significantly different $(\mathrm{p}=0.05)$.

Table.3 Degradation of oxalic acid by bio control agents

\begin{tabular}{|c|l|c|}
\hline Treatment & \multicolumn{1}{|c|}{ Isolates } & $\begin{array}{c}\text { *oxalic acid production } \\
(\mathrm{mg} / \mathrm{ml})\end{array}$ \\
\hline $\mathrm{T}_{1}$ & $\mathrm{Tv1}$ & $2.50^{\mathrm{b}}$ \\
\hline $\mathrm{T}_{2}$ & $\mathrm{Tsp}_{\mathrm{K}}$ & $2.53^{\mathrm{b}}$ \\
\hline $\mathrm{T}_{3}$ & $\mathrm{Tsp}_{\mathrm{T}}$ & $1.05^{\mathrm{a}}$ \\
\hline $\mathrm{T}_{4}$ & Pf1 & $2.53^{\mathrm{b}}$ \\
\hline $\mathrm{T}_{5}$ & Bsp $\mathrm{K}$ & $3.32^{\mathrm{d}}$ \\
\hline $\mathrm{T}_{6}$ & Bacillus amyloliquefaciens & $2.7^{\mathrm{c}}$ \\
\hline $\mathrm{T}_{7}$ & Control & $3.7^{\mathrm{e}}$ \\
\hline & CD $(\mathbf{p}=\mathbf{0 . 0 5})$ & 0.10 \\
\hline
\end{tabular}

*Mean of five replications

The treatment means are compared using Duncan multiple range test (DMRT)

In a column, mean followed by a common letter ( $\mathrm{s}$ ) are not significantly different $(\mathrm{p}=0.05)$ 
They isolated and maintained eight Trichoderma harzianum isolates and eleven T. viride isolates from various rhizosphere soil of plantation crops, forest soil and agricultural fields collected from Northern West Bengal region. These isolates were analysed by ITS amplification using the primers ITS 1 and ITS 4. The amplified product is of $600 \mathrm{bp}$ in length which is seen in all the isolates.

\section{Degradation of oxalic acid by bio control agents}

The result indicated that $T$. harzianum reduced the oxalic acid production of the pathogen to $1.05 \mathrm{mg} / \mathrm{ml}$ in culture filtrate as against the control of $(3.7 \mathrm{mg} / \mathrm{ml})$ followed by Tv1 and $\operatorname{Tsp}_{\mathrm{K}}(2.50$ and $2.53 \mathrm{mg} / \mathrm{ml}$ respectively) and these two were on par with each other. Oxalic acid production was not

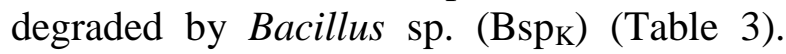
Paramasivan et al., (2013) discovered that while testing the culture filtrate containing both $T$. viride (TVB1) and $S$. rolfsii, TVB1 very much reduced the oxalic acid $(0.79$ $\mathrm{mg} / \mathrm{ml}$ culture filtrate) compared to control $3.07 \mathrm{mg} / \mathrm{ml}$. In this current study the best antagonist reduced the oxalic acid concentration upto $1.05 \mathrm{mg} / \mathrm{ml}$ culture filtrate compared to control $(3.75 \mathrm{mg} / \mathrm{ml})$. Oxalic acid degradation by Trichoderma spp. is the very effective approach in biological control of wilt disease.

Increased levels of phenol accumulation were observed in $T$. viride (TVB1), T. harzianum (THB1), $P$. fluorescens (SBHRPF2) $P$. chlororaphis (PA23) and B. subtilis (SBHRPBS1) pretreated groundnut plants challenge with $S$. rolfsii (Paramasivan et al., 2013).When these Trichoderma spp are applied in the plant ecosystem by seed treatment and soil application, these antagonists contain the pathogen by mechanisms like mycoparasitism, production of antibiotics, degradation of toxins of pathogens and production of volatile compounds. So, exploration of Trichoderma spp. and external application of these antagonists to the field ecosystem by various formulations are highly needed to check many soil borne pathogens causing heavy yield loss in various crops.

\section{References}

Aycock, R. (1966). Stem rot and other disease caused by Sclerotium rolfsii. North Carolina Agric. Exp. Sta. Tech. Bull., No, 174-202.

Bhagat, S., Birah, A., Kumar, R., Yadav, M., and Chattopadhyay, C. (2014). Plant disease management: prospects of pesticides of plant origin Advances in Plant Biopesticides (pp. 119-129): Springer.

Billah, K. M. (2017). Pathogenicity of Sclerotium Rolfsii on Different Host, and Its over Wintering Survival; A Mini Review. International Journal of Advances in Agriculture Sciences, 2(1).

Chakraborty, B. N., Chakraborty, U., Saha, A., Dey, P., and Sunar, K. (2010). Molecular characterization of Trichoderma viride and Trichoderma harzianum isolated from soils of North Bengal based on rDNA markers and analysis of their PCR-RAPD profiles. Global Journal of Biotechnology and Biochemistry, 5(1), 55-61.

Chaurasia, A. K., Chaurasia, S., Chaurasia, S., and Chaurasia, S. (2014). In vitro efficacy of fungicides against the growth of foot-rot pathogen (Sclerotium rolfsii sacc.) of Brinjal. Int. J. Curr. Microbiol. App. Sci, 3(12), 477-485.

Chet, I. (1975). Ultrastructural basis of sclerotial survival in soil. Microbial ecology, 2(3), 194-200. 
Dennis, C., and Webster, J. (1971). Antagonistic properties of speciesgroups of Trichoderma: I. Production of non-volatile antibiotics. Transactions of the British Mycological Society, 57(1), 25-IN23.

Elad, Y., Chet, I., Boyle, P., and Henis, Y. (1983). Parasitism of Trichoderma spp. on Rhizoctonia solani and Sclerotium rolfsii-scanning electron microscopy and fluorescence microscopy. Phytopathology, 73(1), 85-88.

Harman, G. E., Howell, C. R., Viterbo, A., Chet, I., and Lorito, M. (2004). Trichoderma species-opportunistic, avirulent plant symbionts. Nature reviews microbiology, 2(1), 43.

Kubicek, C., Mach, R., Peterbauer, C., and Lorito, M. (2001). Trichoderma : from genes to biocontrol. Journal of Plant Pathology, 11-23.

Mahadevan, A., and Sridar, R. (1986). Methods in physiological plant pathology III ed., Sivakami publications, Madras.

Pandey, K., and Upadhyay, J. (2000). Microbial population from rhizosphere and non-rhizosphere soil of pigeonpea: screening for resident antagonist and mode of mycoparasitism. Journal of Mycology and Plant Pathology, 30(1), 7-10.
Paramasivan, M., Mohan, S., Muthukrishnan, N., and Chandrasekaran, A. (2013). Degradation of oxalic acid (OA) producing Sclerotium rolfsii (Sacc.) by organic biocides. Archives of phytopathology and plant protection, 46(3), 357-363.

Pramer, D., and Schmidt, E.L., 1956. Experimental Soil Microbiol., Buffer Publ. Co., Minneapolis, 107

Ranaswami, G. (1993). Diseases of crop plants in India. Prentice - Hall of India Pvt. Ltd., New Delhi, 489.

Rolfs, P. H. (1893). The tomato and some of its diseases: Florida Agricultural Experiment Station.

Saccardo, P. A. (1911). Note mycologicae. Annales Mycologici, 9, 249-257.

Tang, W., Kuang, J., and Qiang, S. (2015). The pathogenicity of Sclerotium rolfsii on Cyperus difformis and its potential host specificity among the Genus Cyperus. Plant Pathology and Microbiology.

Wang, P., Feng, X., Wang, G., Dong, B., and Li, F. (1999). Screening and identification of PGPR strains isolated from the rhizosphere of winter wheat (Triticum aestivum L.). Journal Huazhong (Central China) Agricultural University, 18(4), 352-356.

\section{How to cite this article:}

Priyadharcini, M., R. Akila, M.L. Mini, N. Rajinimala and Kannan, R. 2018. Exploration of Trichoderma spp. as an Effective Bio Control Agents against the Sclerotial wilt Caused by Sclerotium rolfsii Sacc. Int.J.Curr.Microbiol.App.Sci. 7(08): 1672-1682. doi: https://doi.org/10.20546/ijcmas.2018.708.192 